\title{
Annual Medics and Related Species as Reseeding Legumes for Northern Utah Pastures
}

\author{
M.D. RUMBAUGH AND D.A. JOHNSON
}

\begin{abstract}
Legumes are beneficial in providing high quality forage and enhancing fertility levels in the soil by biological nitrogen fixation. Nonperennial Medicago species have a world-wide distribution and have been used successfully for grazing in Mediterranean-type environments. The feasibility of using nonperennial Medicago species as reseeding pasture legumes in the northern Utah area was evaluated at 2 locations in replicated plantings of 584 accessions representing 34 Medicago species. These nurseries were planted in the spring of 1981 and data were collected through the 1983 growing season. Most of the species were easily established at both test sites. Many grew more rapidly during the seeding year than did the perennial check, $M$. falcata $L$. However, no annual or biennial species was as well nodulated or reduced acetylene on a per plant basis as well as $M$. falcata. None of the populations matured, reproduced, and initiated soil seed bank at the droughtier of the 2 locations. M. Laciniata (L.) Mill., M. lupulina L., M. murex Willd., and $M$. muricoleptis Tin. excelled in the numbers of seedlings per meter of area established by natural reseeding in the fall of the first year of test. However, only $M$. lupulina (black medic) produced abundant seedlings during the second year following seeding. Results indicated that $M$. Iupulina could develop a soil seed bank more rapidly than the other species. Black medic also had superior ground cover characteristics during the second and third years after sowing. Adapted populations of $M$. lupulina appear to have long-term value for forage production in Utah rangeland pastures with suitable soils and adequate precipitation.
\end{abstract}

The genus Medicago consists of 1 shrub, 21 herbaceous perennials, and 34 herbaceous annual species (Lesins and Lesins 1979). It includes the world's most important forage legume, alfalfa (Medicago falcata L., $M$. sativa $L$., and their hybrids). The annual species are known collectively as "medics" or "burr clovers". Medics evolved in North Africa and the Middle-East where they grow over a wide range of soils, temperature regimes, and lengths of growing season (Ewing 1983).

Several species of medic now occur in North America, and some are occasionally cultivated in the United States. Spotted or Southern burr clover $[M$. arabica (L.) Huds.], Tifton burr clover $(\boldsymbol{M}$. rigidula Desr.), barrel medic ( $M$. truncatula Gaertn.), and California or toothed burr clover ( $M$. hispida Gaertn.) are used as winter annual pasture legumes where temperatures are mild. Their distribution, however, is generally restricted to the southern states and the Pacific Coast west of the Cascade and Sierra Nevada mountain ranges. Cog-wheel burr clover ( $M$. tuberculata Willd.) was recommended for pasture usage in the east central area of Texas (Henson and Hollowell 1960). Little burr clover (M. minima Bart.) has been reported to occur in several of the southern states. $M$. orbicularis Bart., called "button clover", grows wild in parts of Tennessee and has been seeded sporadically in northeastern Texas (Davis et al. 1957, Wheeler 1950). Forage yields and protein concentrations were increased when button clover was added to grass or cereal pastures. It should be noted that the common names often used for medics in the United States are not the same as those used in

\footnotetext{
Authors are research geneticist and plant physiologist, USDA-ARS, Crops Research Laboratory, UMC-63, Utah State University, Logan 84322.

The authors appreciate the helpful suggestions of E.J. Crawford, Senior Plant Introduction Officer, South Australian Dept. of Agriculture, Adelaide, while planning the research and for many of the seeds used in the experiments. The research is a contribution from the USDA-ARS and the Utah Agricultural Experiment Station, Logan. Journal Paper No. 3056.

Manuscript accepted 30 May 1985.
}

Australia for the identical species.

Figure 1 illustrates the annual climatic patterns of precipitation and temperature at a locality where medics are indigenous (Tunis, Tunisia), and where they have been successfully introduced (Los Angeles, CA). Most medic species are winter annuals adapted to Mediterranean climates. Their usual life cycle is to germinate with the onset of the first fall rains in September to November and to grow rapidly while warm temperatures and precipitation coincide. While the growth rate may be reduced during winter, flowering usually is completed during April. In colder temperate climates, these species would have to be used as spring annuals.

Self-seeding annual legumes may be better adapted to arid rangelands than perennial legumes. Quinlivan (1971) showed that medics can survive many years of drought due to the hardseed mechanism. In addition, although annual medics have no means for evading dry seasonal conditions by earlier flowering, their phasic development can be accelerated by drought stress once flowering has begun (Clarkson and Russell 1976). Their successful adaptation to arid environments is evidenced by the presence of several medic species in regions of North Africa receiving less than $250 \mathrm{~mm}$ of annual precipitation (Francis 1981). Furthermore, Tadmor et al. (1971) considered medics to be among the best adapted plants for practical desert range development in the 80 - to $100-\mathrm{mm}$ winter rainfall region of the Negev Desert in Israel.

The objective of the present study was to evaluate the developmental characteristics of medics when used as spring and early summer reseeding annual legumes in a cold winter desert environment.

\section{Materials and Methods}

Seeds for experiments were obtained from the USDA Regional Plant Introduction Station, Experiment, Georgia, and from the South Australian Department of Agriculture, Adelaide, South Australia. A total of 584 Medicago accessions representing 34 species and originally collected in 39 countries were included. Two species ( 4 accessions) were long-lived perennials, 1 species (70 accessions) was a short-lived perennial, and the remainder were annuals. The species identifications designated by the seed source agencies were retained. All seeds were scarified and treated with commercial peat base inoculants of appropriate Rhizobium meliloti Dang. strains immediately prior to sowing.

Clean tilled nurseries were seeded in Cache Valley near Logan, Utah $\left(41^{\circ} 45^{\prime} \mathrm{N}, 111^{\circ} 48^{\prime} \mathrm{W}, 1389 \mathrm{~m}\right)$ and Curlew Valley near Snowville, Utah $\left(41^{\circ} 57^{\prime} \mathrm{N}, 112^{\circ} 42^{\prime} \mathrm{W}, 1411 \mathrm{~m}\right)$ on 6 April 1981 and 14 April 1981, respectively. Twenty-five seeds were hand planted in a single row within each meter-long plot. The plots were spaced 1 meter apart within rows and 2 meters apart between rows. The experimental designs at each location were 2 replicate randomized complete blocks with the randomization restricted so that all accessions of each species were retained together within incomplete blocks. Weeds were controlled throughout the experiments by hand cultivation. Relative maturities of the accessions were quantified by recording the date on which the first fully opened flower was observed in each plot. Seedlings were counted and ground cover visually estimated within a circular $1.0-\mathrm{m}^{2}$ frame centered on each plot. Plant widths and heights were measured on the widest and tallest plants within each plot and, therefore, are maximum values for the test environment. The degree of pod spininess was scored visually on a 1 to 3 scale and other traits scored on a 1 to 9 


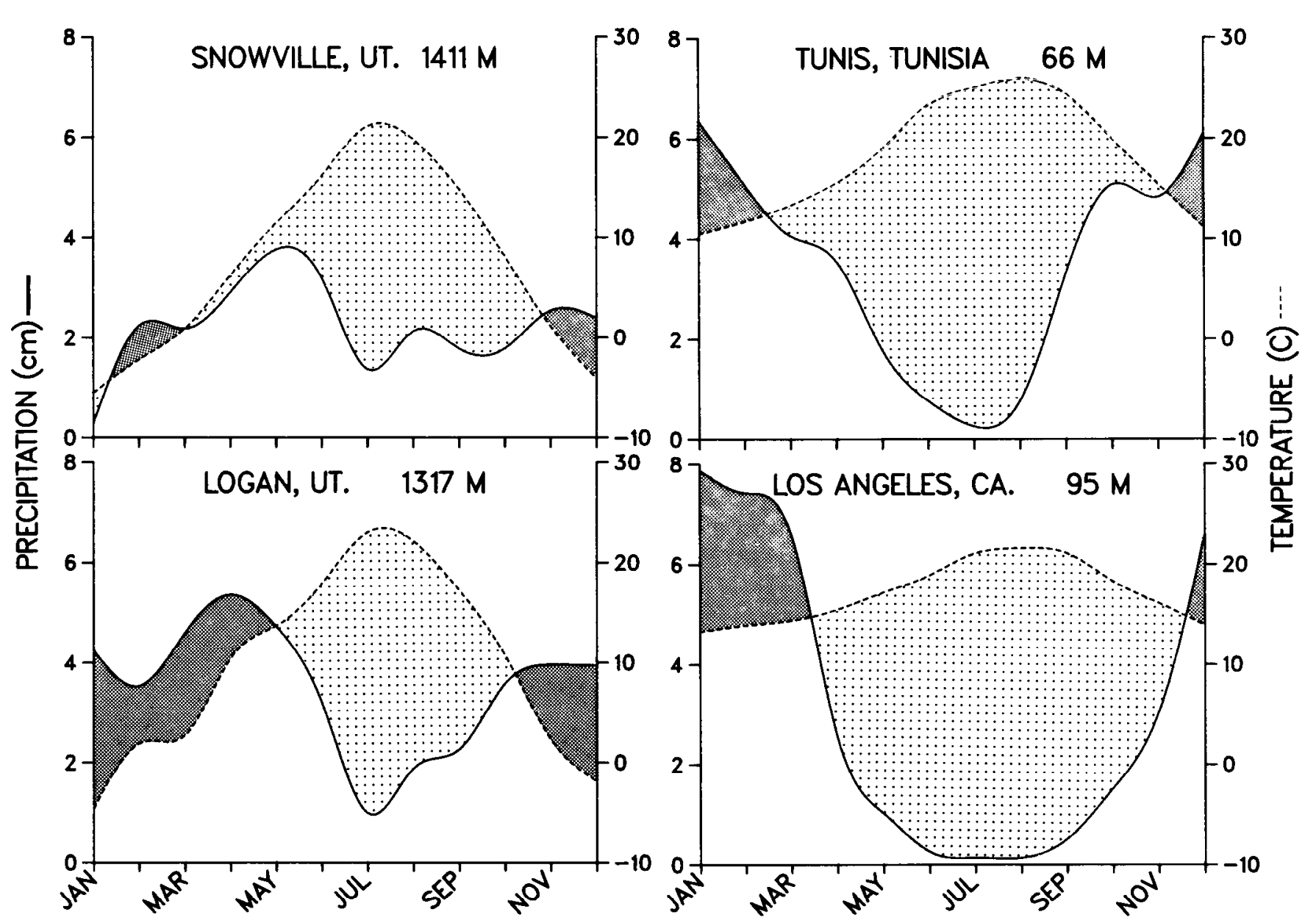

Fig. 1. Mean monthly temperature and precipitation at 2 locations with a Mediterranean climate (Tunis, Tunisia, and Los Angeles, Calif.) and at 2 locations with a cool desert climate (Logan, Utah, and Snowville, Utah). Modified from Walter and Lieth (1960).

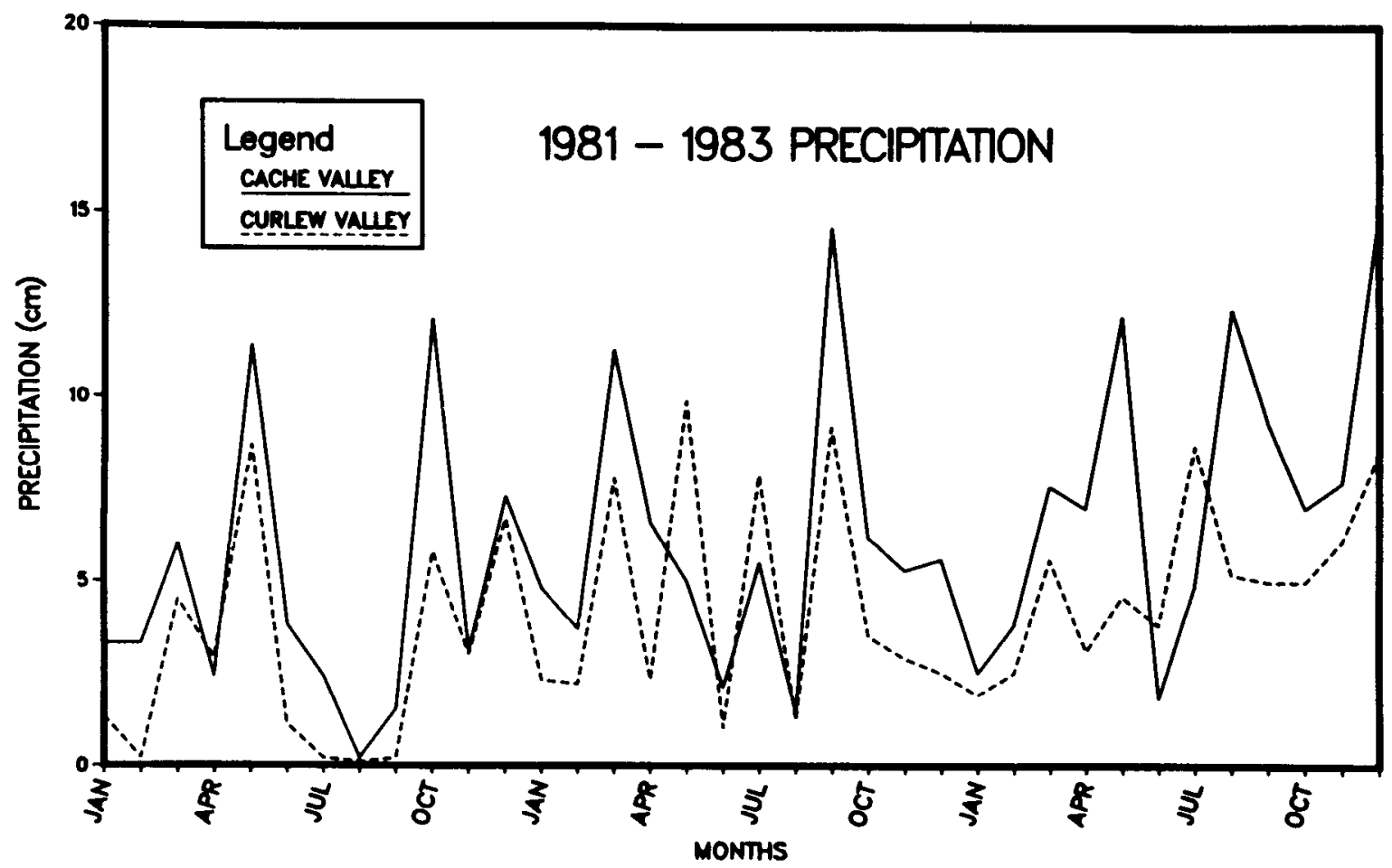

Fig. 2. Precipitation in Cache Valley (Logan, Utah) and Curlew Valley (Snowville, Utah) for 1981 through 1983. 
scale with the lowest figure representing the most desirable and the highest figure the least desirable expression of the traits.

During the third week of June 1981, one or more accessions within each species which exhibited above-average shoot biomass were sampled in the field to estimate nitrogen fixation activity. One plant within each plot was excavated with minimal disturbance of the adjacent plants. Nitrogen fixation activity and leaf water potential were estimated in the field by the acetylene reduction and pressure chamber techniques described by Johnson and Rumbaugh (1981) and by Scholander et al. (1965), respectively.

\section{Results and Discussion}

Long-term average precipitation at the U.S. weather stations nearest the plantings (Logan and Snowville, Utah) is shown in Figure 1 and that for the 3 years of study is presented in Figure 2. Both sites received low amounts of precipitation during July through September of 1981 with 4.1 and $0.5 \mathrm{~cm}$ of rainfall in Cache Valley and Curlew Valley, respectively. Maximum daily temperatures during the summer of 1981 exceeded recent historical averages for Cache Valley by only $0.1^{\circ} \mathrm{C}$ but those for Curlew Valley were $2.4^{\circ} \mathrm{C}$ above average (Table 1 ). The higher temperatures and
Table 1. Average daily maximum temperatures $(C)$ at the recording stations nearest the test sites.

\begin{tabular}{lccccc}
\hline \hline & \multicolumn{2}{c}{ Cache Valley } & & \multicolumn{2}{c}{ Curlew Valley } \\
\cline { 2 - 3 } \cline { 5 - 6 } Month & 1981 & $\begin{array}{c}\text { Average } \\
1951-1980\end{array}$ & & 1981 & $\begin{array}{c}\text { Average } \\
1951-1980\end{array}$ \\
\hline May & 17.7 & 20.0 & & 20.0 & 20.7 \\
June & 24.8 & 25.1 & & 28.1 & 26.4 \\
July & 30.6 & 30.1 & & 34.7 & 32.5 \\
August & 31.1 & 29.5 & & 35.5 & 31.0 \\
September & 25.2 & 24.1 & & 29.8 & 25.4 \\
\hline
\end{tabular}

lower precipitation during the first growing season resulted in greater potential drought stress at the Curlew Valley test site than at Cache Valley. The subsequent 2 years of the experiments, 1982 and 1983, were years of above-average precipitation.

Most of the Medicago species successfully germinated and emerged at both the Cache Valley and Curlew Valleys sites in the

Table 2. Developmental characteristics of Medicago species grown in Cache Valley, Utah.

\begin{tabular}{|c|c|c|c|c|c|c|c|c|c|c|c|c|c|c|c|}
\hline & \multirow{2}{*}{$\begin{array}{c}\text { Number } \\
\text { of } \\
\text { acces- } \\
\text { sions }\end{array}$} & \multirow{2}{*}{$\begin{array}{c}\text { Growth } \dagger \\
\text { habit }\end{array}$} & \multirow{2}{*}{$\begin{array}{l}50 \text { seed } \\
\text { weight } \\
(\mathrm{g})\end{array}$} & \multirow{2}{*}{$\begin{array}{c}\begin{array}{c}\text { Initial } \downarrow \\
\text { stand }\end{array} \\
\text { (score) }\end{array}$} & \multirow{2}{*}{$\begin{array}{l}\text { Shoot } \neq \\
\text { biomass } \\
\text { (score) }\end{array}$} & \multicolumn{2}{|c|}{$\begin{array}{l}1981 \text { day of } \\
\text { first bloom }\end{array}$} & \multirow{2}{*}{$\begin{array}{c}\begin{array}{c}\text { Pod } \ddagger \\
\text { abun- } \\
\text { dance }\end{array} \\
\text { (score) }\end{array}$} & \multirow{2}{*}{$\begin{array}{l}\text { Spine } \\
\text { length } \\
\text { (score) }\end{array}$} & \multicolumn{2}{|c|}{$\begin{array}{c}\text { Plant } \\
\text { size }(\mathrm{cm})^{*}\end{array}$} & \multicolumn{2}{|c|}{$\begin{array}{l}\text { Seedling density } \\
\text { (number } / \mathrm{m} \text { ) }\end{array}$} & \multicolumn{2}{|c|}{ Ground cover $(\%)$} \\
\hline & & & & & & Numerical & Date & & & Width & Height & $10-22-81$ & $7-10-82$ & $7-19-82$ & $5-25-83$ \\
\hline M. aculeata & 6 & A & 0.49 & 4.7 & 3.6 & 158 & 7 June & 7.9 & 3.0 & 91 & 12 & 182 & 7 & 39 & 8 \\
\hline M. arabica & 13 & A & 0.11 & 5.3 & 5.7 & 171 & 20 June & 8.0 & 3.0 & 71 & 10 & 233 & 4 & 10 & 7 \\
\hline M. arborea & 1 & $\ddot{\mathbf{p}}$ & 0.35 & 8.0 & 8.0 & - & - & 9.0 & - & 63 & 28 & 1 & 2 & 0 & 0 \\
\hline M. achersoniana & 1 & A & 0.13 & 8.0 & 8.0 & 206 & 25 July & 9.0 & 1.0 & 92 & 10 & 150 & 3 & 35 & 30 \\
\hline M. blancheana & 3 & A & 0.38 & 3.3 & 5.5 & 170 & 19 June & 5.8 & 1.3 & 51 & 31 & 33 & 2 & 2 & 4 \\
\hline$M$. constricta & 16 & A & 0.23 & 4.8 & 6.8 & 174 & 23 June & 7.3 & 3.0 & 102 & 11 & 256 & 9 & 20 & 38 \\
\hline M. disciformis & 5 & A & 0.16 & 5.7 & 6.6 & 181 & 30 June & 8.2 & 3.0 & 92 & 12 & 158 & 4 & 14 & 8 \\
\hline M. falcata & 3 & $\mathrm{P}$ & 0.11 & 7.8 & 5.5 & 168 & 17 June & 9.0 & 1.0 & 182 & 62 & 21 & 3 & 9 & 1 \\
\hline M. gerardii & 2 & A & 0.21 & 6.2 & 6.0 & 180 & 29 June & 9.0 & 3.0 & 89 & 6 & 292 & 14 & 36 & 38 \\
\hline M. granadensis & 1 & A & 0.55 & 5.0 & 4.5 & 188 & 7 July & 9.0 & 3.0 & 76 & 26 & 114 & 4 & 30 & 0 \\
\hline$M$. intertexta & 2 & A & 0.65 & 2.0 & 1.2 & 183 & 2 July & 8.2 & 3.0 & 85 & 25 & 55 & 8 & 8 & 0 \\
\hline M. laciniata & 1 & A & 0.12 & 3.5 & 7.0 & 169 & 18 June & 8.0 & 3.0 & 156 & 10 & 708 & 16 & 68 & 0 \\
\hline M. littoralis & 14 & A & 0.13 & 3.7 & 5.0 & 160 & 9 June & 6.4 & 2.6 & 95 & 16 & 276 & 13 & 19 & 2 \\
\hline M. lupulina & 70 & B & 0.07 & 6.2 & 7.6 & 169 & 18 June & 4.4 & 1.0 & 155 & 22 & 931 & 3,806 & 91 & 54 \\
\hline M. minima & 13 & $\mathbf{A}$ & 0.08 & 6.2 & 7.5 & 160 & 9 June & 5.5 & 2.9 & 78 & 14 & 299 & 91 & 25 & 12 \\
\hline M. murex & 6 & A & 0.16 & 4.9 & 6.5 & 167 & 16 June & 2.5 & 2.9 & 96 & 14 & 658 & 6 & 18 & 1 \\
\hline M. muricata & 1 & A & 0.07 & 4.5 & 8.0 & 178 & 27 June & 3.0 & 3.0 & 79 & 20 & 271 & 3 & 18 & 15 \\
\hline M. muriculeptis & 1 & A & 0.37 & 6.0 & 7.5 & 181 & 30 June & 9.0 & 2.5 & 124 & 4 & 790 & 3 & 18 & 0 \\
\hline$M$. noeana & 11 & A & 0.18 & 3.3 & 6.5 & 181 & 30 June & 8.4 & 1.4 & 94 & 24 & 141 & 16 & 21 & 6 \\
\hline M. obscura & 2 & A & 0.18 & 4.8 & 5.8 & 173 & 22 June & 5.5 & 2.0 & 121 & 21 & 300 & 10 & 22 & 0 \\
\hline M. orbicularis & 100 & $\mathbf{A}$ & 0.18 & 7.0 & 7.5 & 186 & 5 July & 7.7 & 1.0 & 79 & 10 & 157 & 4 & 14 & 6 \\
\hline M. polymorpha & 111 & A & 0.18 & 4.3 & 5.6 & 157 & 6 June & 3.0 & 2.7 & 71 & 20 & 242 & 9 & 15 & 3 \\
\hline M. praecox & 1 & $\mathbf{A}$ & 0.09 & 4.5 & 8.0 & 172 & 21 June & 5.5 & 3.0 & 66 & 10 & 119 & 6 & 22 & 15 \\
\hline$M$. radiata & 2 & $\mathbf{A}$ & 0.22 & 6.2 & 7.2 & 169 & 18 June & 6.0 & 1.0 & 34 & 23 & 44 & 4 & 18 & 1 \\
\hline M. rigidula & 58 & $\mathbf{A}$ & 0.22 & 4.0 & 7.2 & 172 & 21 June & 7.3 & 2.9 & 105 & 13 & 353 & 8 & 37 & 16 \\
\hline$M$. rotata & 8 & A & 0.30 & 4.8 & 6.6 & 157 & 6 June & 5.1 & 2.3 & 57 & 23 & 79 & 2 & 6 & 0 \\
\hline$M$. rugosa & 4 & A & 0.48 & 2.5 & 4.2 & 171 & 20 June & 5.4 & 1.3 & 94 & 29 & 207 & 51 & 27 & 2 \\
\hline M. sauvagei & 1 & A & 0.25 & 4.5 & 7.5 & 156 & 5 June & 1.0 & 3.0 & 49 & 15 & 111 & 1 & 0 & 0 \\
\hline M. scutellata & 23 & A & 0.77 & 3.9 & 5.5 & 164 & 13 June & 5.4 & 1.0 & 109 & 29 & 175 & 40 & 21 & 2 \\
\hline M. tornata & 25 & A & 0.21 & 4.4 & 5.9 & 156 & 5 June & 6.2 & 1.8 & 94 & 20 & 141 & 6 & 8 & 1 \\
\hline M. tribuloides & 29 & $\mathbf{A}$ & 0.19 & 5.1 & 6.1 & 162 & 11 June & 6.4 & 2.8 & 83 & 15 & 282 & 25 & 24 & 1 \\
\hline M. truncatula & 25 & A & 0.22 & 3.8 & 5.3 & 164 & 13 June & 7.1 & 2.9 & 72 & 14 & 116 & 9 & 12 & 0 \\
\hline M. turberculata & 3 & A & 0.28 & 4.7 & 4.8 & 166 & 15 June & 5.3 & 1.7 & 143 & 24 & 16 & 5 & 21 & 2 \\
\hline M. turbinata & 22 & A & 0.39 & 6.0 & 5.7 & 158 & 7 June & 8.0 & 2.3 & 105 & 14 & 149 & 6 & 22 & 6 \\
\hline Mean & & & 0.21 & 5.1 & 6.4 & 157 & 6 June & 5.9 & 2.2 & 93 & 17 & 274 & 413 & 26 & 12 \\
\hline L.S.D. (0.05) & & & 0.05 & 0.9 & 0.6 & 23 & - & 1.1 & - - & 16 & 4 & 190 & 151 & 11 & 8 \\
\hline$(0.01)$ & & & 0.06 & 1.2 & 0.9 & 31 & - & 1.5 & - & 20 & 5 & 251 & 167 & 15 & 11 \\
\hline
\end{tabular}

$\uparrow A=$ annual, $B=$ biennial, $P=$ perennial

$\ddagger 1=$ most, $9=$ least

$\$ 1=$ no spines; $2=$ =moderate spines; $3=$ long curved spines

* Maximum distances measured on 24 September 1982 
initial establishment year. However, only a few plants were found in the Curlew Valley experiment in 1982 and none in 1983. Therefore, second and third year results were available from Cache Valley only. There was a ninefold range in average seed size among the species tested (Table 2). $M$. aculeata Willd., $M$. granadensis Willd., $M$. intertexta Mill., $M$. rugosa Desr., and $M$. scutellata Mill. excelled in this trait, whereas the 50 seed weights of $M$. lupulina L., M. minima, $M$. muricata Willd., and $M$. praeco DC seeds were less than $0.1 \mathrm{~g}$. Seedlings of large-seeded species were more vigorous and larger than seedlings of small-seeded species. This was reflected in the initial stand and shoot biomass scores recorded on 11 June 1981, 2 months after planting. The associations between seed weight and stand and shoot biomass resulted in significant simple correlation coefficients of $r=0.42(P<0.05)$ and $r$ $=0.66(P<0.01)$, respectively. All of the 5 large-seeded species mentioned are adapted to heavy, wet, clay soils (Lesins and Lesins 1979). $M$. aculeata is considered by some authorities, including Urban (1873), to be a botanical variety of $M$. turbinata All.

The habits of the small-seeded species differ. M. minima is one of the most widely distributed and the most variable annual medic. It commonly is found growing in dry soils on rocky hillsides or in sands of the Mediterranean region. M. muricata was considered by Lesins and Lesins (1979) to be a form of the polymorphic species, M. tornata Mill.. In its natural habitat, it too is found on sandy soils or at least on sites with only a thin layer of dry, loose soil on top of rock. Similarly, $M$. praecox is best adapted to sandy soils of droughty sites. $M$. lupulina is quite different than the other smallseeded medics discussed because it grows best in moister soils and cooler temperatures than the expressly annual Medicago species. Most populations of black medic in northern Great Basin areas occur at elevations higher than approximately $1,400 \mathrm{~m}$ and are short-lived perennials.

Early maturity would be a desirable trait of species selected for northern Utah rangeland pastures so that plants could form seed pods prior to the summer drought stress period. Average date of first bloom of the medic species in 1981 varied from 5 June for $M$. sauvegei Negre and $M$. tornata to 25 July for $M$. achersoniana Urb. (Table 2). Accessions not flowering until July would usually be exposed to very restricted soil moisture availability during their reproductive development, and immature or aborted pods would result. This interpretation is supported by the pod abundance scores recorded on 7 July 1981 . M. sauvagei, the earliest flowering species, produced more pods per plant than any other medic. The Pearson correlation coefficient for date of first bloom and pod abundance score was $r=0.53(P<0.01)$.

Long pod spines, especially if they are curved, are undesirable because they may become caught in the wool of grazing sheep. Several medics have pods of that type but others do not (Table 2). There is ample genetic variation within a number of the species to select for types with less prominent spines.

Table 3. Characteristics related to nitrogen fixation activity of Medicago species when grown in Cache Valley, Utah.

\begin{tabular}{|c|c|c|c|c|c|c|c|c|}
\hline \multirow[b]{2}{*}{ Species } & \multirow{2}{*}{$\begin{array}{c}\text { Plants } \\
\text { tested } \\
\text { (number) }\end{array}$} & \multirow{2}{*}{$\begin{array}{c}\text { Leaf water } \\
\text { potential } \\
(-\mathrm{MPa})\end{array}$} & \multicolumn{4}{|c|}{ Plant weight (g) } & \multirow{2}{*}{$\begin{array}{l}\text { Nodules per } \\
\text { plant } \\
\text { (number) }\end{array}$} & \multirow{2}{*}{$\begin{array}{c}\begin{array}{c}\text { Acetylene reduction } \\
\text { activity } \dagger\end{array} \\
\text { nanomoles/h/plant }\end{array}$} \\
\hline & & & Shoot & Root & Nodules & Total & & \\
\hline M. aculeata & 6 & 0.66 & 6.98 & 0.19 & 0.0017 & 7.17 & 7.8 & 6.7 \\
\hline M. arabica & 6 & 0.78 & 2.18 & 0.19 & 0.0012 & 2.37 & 13.5 & 9.4 \\
\hline$M$. arborea & 3 & 0.62 & 0.17 & 0.04 & 0.0003 & 0.20 & 4.0 & 16.5 \\
\hline M. blancheana & 6 & 0.94 & 2.76 & 0.09 & 0.0017 & 2.85 & 8.5 & 8.9 \\
\hline M. constricta & 6 & 0.80 & 3.59 & 0.10 & 0.0003 & 3.69 & 3.5 & 4.9 \\
\hline M. disciformis & 6 & 0.83 & 3.65 & 0.14 & 0.0003 & 3.78 & 2.5 & 7.4 \\
\hline M. falcata & 3 & 0.80 & 2.22 & 0.52 & 0.0025 & 2.74 & 22.3 & 13.4 \\
\hline M. gerardii & 3 & 0.95 & 6.66 & 0.40 & 0.0027 & 7.07 & 12.7 & 4.1 \\
\hline M. granadensis & 5 & 0.70 & 5.58 & 0.19 & 0.0035 & 5.77 & 17.6 & 2.7 \\
\hline$M$. intertexta & 6 & 0.70 & 4.07 & 0.21 & 0.0007 & 4.28 & 3.2 & 6.6 \\
\hline M. laciniata & 6 & 0.94 & 1.93 & 0.09 & 0.0002 & 2.02 & 2.7 & 2.2 \\
\hline M. littoralis & 6 & 0.94 & 4.60 & 0.14 & 0.0005 & 4.73 & 3.7 & 2.5 \\
\hline M. lupulina & 6 & 0.86 & 1.44 & 0.10 & 0.0010 & 1.54 & 9.0 & 6.2 \\
\hline M. minima & 5 & 1.04 & 2.68 & 0.11 & 0.0008 & 2.79 & 9.2 & 8.7 \\
\hline M. murex & 5 & 0.80 & 1.92 & 0.09 & 0.0008 & 2.01 & 4.8 & - \\
\hline M. muricata & 6 & 0.94 & 1.40 & 0.10 & 0.0003 & 1.50 & 8.0 & - \\
\hline M. muricoleptis & 3 & 0.67 & 1.31 & 0.14 & 0.0004 & 1.45 & 6.7 & 2.1 \\
\hline M. noeana & 6 & 1.02 & 2.28 & 0.09 & 0.0000 & 2.36 & 0.8 & 3.1 \\
\hline M. obscura & 11 & 0.96 & 3.57 & 0.15 & 0.0004 & 3.72 & 3.5 & 3.6 \\
\hline M. orbicularis & 6 & 0.98 & 6.50 & 0.15 & 0.0008 & 6.64 & 11.0 & 1.0 \\
\hline M. polymorpha & 6 & 0.97 & 7.51 & 0.21 & 0.0026 & 7.72 & 12.8 & 4.1 \\
\hline M. praecox & 5 & 1.01 & 0.75 & 0.05 & 0.0002 & 0.80 & 1.8 & 0.0 \\
\hline$M$. radiata & 5 & 0.74 & 1.62 & 0.07 & 0.0004 & 1.70 & 1.4 & - \\
\hline$M$. rigidula & 3 & 1.03 & 1.96 & 0.08 & 0.0001 & 2.04 & 1.0 & - \\
\hline$M$. rotata & 6 & 0.88 & 4.06 & 0.15 & 0.0005 & 4.21 & 7.5 & - \\
\hline M. rugosa & 6 & 0.82 & 4.85 & 0.30 & 0.0040 & 5.16 & 16.0 & 59.3 \\
\hline M. sauvagei & 5 & 1.22 & 1.04 & 0.05 & 0.0001 & 1.09 & 0.4 & - \\
\hline M. scutellata & 5 & 1.12 & 3.12 & 0.16 & 0.0015 & 3.28 & 5.4 & 0.6 \\
\hline M. tornata & 6 & 1.26 & 7.64 & 0.16 & 0.0014 & 7.80 & 6.0 & 0.2 \\
\hline M. tribuloides & 3 & 1.11 & 7.34 & 0.23 & 0.0027 & 7.57 & 7.3 & 3.5 \\
\hline M. truncatula & 4 & 0.84 & 6.56 & 0.34 & 0.0005 & 6.90 & 4.8 & - \\
\hline M. turberculata & 6 & 1.00 & 4.21 & 0.18 & 0.0010 & 4.39 & 9.8 & 28.6 \\
\hline M. turbinata & 5 & 1.08 & 7.86 & 0.30 & 0.0025 & 8.17 & 10.8 & 16.0 \\
\hline Mean & 5 & 0.92 & 3.80 & 0.16 & 0.0011 & 3.96 & 7.1 & 6.5 \\
\hline L.S.D. (0.05) & - & 0.14 & 2.98 & 0.10 & 0.0010 & 3.05 & 7.0 & N.S. \\
\hline$(0.01)$ & - & 0.18 & 3.94 & 0.13 & 0.0014 & 4.03 & 9.2 & N.S. \\
\hline
\end{tabular}

†Values were omitted when the background correction exceeded the sample activity. 
Table 4. Characteristics related to nitrogen fixation activity of Medicago species when grown in Curlew Valley, Utah.

\begin{tabular}{|c|c|c|c|c|c|c|c|c|}
\hline \multirow[b]{2}{*}{ Species } & \multirow{2}{*}{$\begin{array}{c}\text { Plants } \\
\text { tested } \\
\text { (number) }\end{array}$} & \multirow{2}{*}{$\begin{array}{c}\text { Leaf water } \\
\text { potential } \\
(-\mathrm{MPa})\end{array}$} & \multicolumn{4}{|c|}{ Plant weight (g) } & \multirow{2}{*}{$\begin{array}{l}\text { Nodules per } \\
\text { plant } \\
\text { (number) }\end{array}$} & \multirow{2}{*}{$\begin{array}{l}\text { Acetylene reduction } \\
\text { activity } \dagger \\
\text { nanomoles/h/plan }\end{array}$} \\
\hline & & & Shoot & Root & Nodules & Total & & \\
\hline M. aculeata & 5 & 1.72 & 2.68 & 0.11 & 0.0155 & 2.81 & 16.2 & 9.0 \\
\hline M. arabica & 1 & 1.70 & 0.55 & 0.04 & 0.0021 & 0.59 & 10.0 & 3.0 \\
\hline M. arborea & 3 & 2.80 & 0.08 & 0.02 & 0.0000 & 0.10 & 0.0 & - \\
\hline M. blancheana & 4 & - & 0.09 & 0.01 & 0.0010 & 0.11 & 1.8 & 0.5 \\
\hline M. constricta & 5 & 2.09 & 1.01 & 0.05 & 0.0013 & 1.06 & 7.6 & 2.4 \\
\hline M. disciformis & 2 & 1.68 & 0.16 & 0.01 & 0.0000 & 0.17 & 1.0 & 1.7 \\
\hline M. falcata & 1 & - & 0.19 & 0.01 & 0.0115 & 0.21 & 18.0 & 3.5 \\
\hline M. gerardii & 4 & 1.85 & 1.60 & 0.12 & 0.0087 & 1.73 & 11.8 & 6.6 \\
\hline M. granadensis & 3 & 1.35 & 2.08 & 0.12 & 0.0019 & 2.20 & 5.0 & 0.6 \\
\hline$M$. intertexta & 5 & 2.45 & 0.34 & 0.06 & 0.0006 & 0.40 & 3.6 & 0.2 \\
\hline M. laciniata & 1 & - & 0.00 & 0.01 & 0.0000 & 0.01 & 0.0 & - \\
\hline M. littoralis & 5 & 1.82 & 0.63 & 0.04 & 0.0014 & 0.69 & 4.2 & 1.4 \\
\hline M. lupulina & 1 & 2.10 & 0.50 & 0.03 & 0.0019 & 0.53 & 4.0 & 2.2 \\
\hline M. minima & 2 & 1.72 & 0.31 & 0.02 & 0.0000 & 0.33 & 0.0 & - \\
\hline M. murex & 5 & 1.71 & 0.22 & 0.02 & 0.0002 & 0.24 & 0.6 & 2.8 \\
\hline M. muricata & 5 & 1.50 & 0.97 & 0.05 & 0.0005 & 1.02 & 1.2 & 3.0 \\
\hline M. muricoleptis & 2 & - & 0.08 & 0.01 & 0.0000 & 0.10 & 0.0 & - \\
\hline M. noeana & 4 & 1.95 & 0.37 & 0.03 & 0.0000 & 0.40 & 0.0 & - \\
\hline M. obscura & 7 & 1.96 & 0.38 & 0.02 & 0.0015 & 0.40 & 2.6 & 0.6 \\
\hline M. orbicularis & 6 & 2.35 & 0.28 & 0.02 & 0.0009 & 0.30 & 4.7 & 0.1 \\
\hline M. polymorpha & 3 & - & 0.03 & 0.01 & 0.0000 & 0.04 & 0.0 & - \\
\hline M. praecox & 3 & - & 0.11 & 0.02 & 0.0010 & 0.14 & 3.3 & 1.1 \\
\hline$M$. radiata & 4 & - & 0.60 & 0.03 & 0.0008 & 0.63 & 2.2 & 0.6 \\
\hline M. rigidula & 5 & 1.73 & 0.95 & 0.07 & 0.0005 & 1.02 & 0.8 & - \\
\hline$M$. rotata & 4 & 1.66 & 0.05 & 0.02 & 0.0000 & 0.07 & 0.0 & - \\
\hline M. rugosa & 5 & - & 0.09 & 0.03 & 0.0000 & 0.12 & 0.0 & - \\
\hline M. sauvagei & 5 & 2.10 & 0.96 & 0.05 & 0.0000 & 1.01 & 0.0 & - \\
\hline M. scutellata & 4 & 1.62 & 0.38 & 0.05 & 0.0079 & 0.44 & 10.2 & 1.8 \\
\hline M. tomata & 4 & 2.01 & 0.64 & 0.02 & 0.0014 & 0.66 & 1.0 & 1.8 \\
\hline M. tribuloides & 3 & 1.55 & 2.95 & 0.09 & 0.0008 & 3.04 & 3.7 & 1.1 \\
\hline M. truncatula & 4 & 1.92 & 0.31 & 0.05 & 0.0038 & 0.37 & 5.5 & 0.7 \\
\hline M. turberculata & 6 & 1.78 & 0.62 & 0.05 & 0.0029 & 0.67 & 5.7 & 2.2 \\
\hline M. turbinata & 4 & 1.75 & 0.17 & 0.03 & 0.0010 & 0.20 & 1.2 & - \\
\hline Mean & 4 & 1.89 & 0.67 & 0.04 & 0.0021 & 0.72 & 3.6 & 1.3 \\
\hline L.S.D. (0.05) & - & 0.40 & 1.11 & 0.05 & 0.0056 & 0.37 & 7.5 & N.S. \\
\hline$(0.01)$ & - & 0.53 & 1.46 & 0.06 & 0.0074 & 0.49 & 9.9 & N.S. \\
\hline
\end{tabular}

† Values were omitted when the background correction exceeded the sample activity or when there were no nodules.

Mean plant width measured on 24 September 1981 varied from 34 to $182 \mathrm{~cm}$ (Table 2). Similarly, mean plant height varied among the species from 4 to $62 \mathrm{~cm}$. The perennial, $M$. falcata, was larger than any of the annual or biennial species. $M$. laciniata (L.) Mill. was the widest and $M$. blancheana Boiss. the tallest of the annuals. $M$. lupulina was among the wider species but of moderate height.

Ability to reseed and seedling survival are absolutely essential for consideration of any plant population as a candidate for longterm pasture usage. Species excelling in number of seedlings per $\mathrm{m}^{2}$ in the fall of the first year were $M$. laciniata, $M$. lupulina, $M$. murex Willd., and $M$. muricoleptis Tin. However, only $M$. lupulina had more than 100 seedlings per $\mathrm{m}^{2}$ in the summer of the second year of the experiment. Medic seedlings usually overwinter at localities with Mediterranean climates (Fig. 1). This is less likely to occur in the Great Basin and sufficient hard seed must be formed to reestablish the population each spring. $M$. Iupulina also was superior to the other species with respect to ground cover capability in both 1982 and 1983. This trait also is considered very important for legumes which are to be included in seed mixtures for range reseeding.

Physiological responses of the Medicago species to the environments of the 2 test sites in 1981 differed (Tables 3 and 4). Plants in Curlew Valley were smaller, possessed fewer nodules, fixed less nitrogen, and had lower leaf water potentials than plants of the same species in Cache Valley. Average total plant weights of the species at the 2 sites were positively and significantly $(P<0.05)$ associated but the correlation coefficient was low, $r=0.38$. Analo- gous correlations for leaf water potentials and acetylene reduction activities were not significantly different from zero. These differences were interpreted as due to greater drought stress in the Curlew Valley nursery. Plants at that site often were visibly wilted, stunted, and died without forming seed. No plants were alive in the third year of experimentation at Curlew Valley but 25 species persisted into the third year in Cache Valley.

Despite large differences among the species in ability to reduce acetylene in the Cache Valley planting, the differences were not statistically significant $(P>0.05)$. The acetylene reduction procedure often results in coefficients of variation of greater magnitude than many other agronomic and physiological measurements. However, assuming that the rankings of means provides a valid indication of relative ability to fix atmospheric nitrogen (Table 3), $M$. rugosa was more active than the other species while $M$. tuberculata ranked second. These values are similar in magnitude to those shown by Baltensperger and Smith (1984) for M. lupulina grown in a nitrogen-free medium in a greenhouse environment. The correlation of numbers of nodules and acetylene reduction activity on a per plant basis for species means was positive, $r=0.41(P<0.05)$ (Table 5). The weights of plant parts also were significantly and positively associated, but only nodule weight significantly influenced acetylene reduction. As judged by the coefficient of determination, $r^{2}$, variation in nodule weight accounted for $24 \%$ of the variation in nitrogen fixation capability. Either nodule number or nodule weight would be useful for evaluating the nitrogen fixation potential of legumes in selection nurseries or in rangeland pasture seeding experiments. 
Table 5. Simple correlations (r) of Medicago traits associated with noduIa tion and acetylene reduction activity in Cache Valley, Utah.

\begin{tabular}{lcc}
\hline \hline & $\begin{array}{c}\text { Nodules } \\
\text { per plant } \\
\text { (number) }\end{array}$ & $\begin{array}{c}\text { Acetylene reduction } \\
\text { activity } \\
\text { (nanomoles/h/plant) }\end{array}$ \\
\hline Sssociated traits & 0.08 & 0.24 \\
Do seed weight (g) & 0.05 & -0.04 \\
Leay of first bloom & 0.19 & 0.09 \\
Shoot weight (g) & $0.34^{*}$ & 0.04 \\
Root weight (g) & $0.70^{* *}$ & 0.26 \\
Nodule weight (g) & $0.80^{* *}$ & $0.49^{* *}$ \\
Total plant weight (g) & $0.37^{*}$ & 0.05 \\
Nodule number & - & $0.41^{*}$ \\
\hline
\end{tabular}

$* P<0.05$

$* P<0.01$

Based on the data obtained in these experiments and summarized in Tables 2 and $3, M$. lupulina apparently has more potential to improve pastures in environments similar to that of Cache Valley during 1981 through 1983 than the annual medics tested. The other species may be more useful in different environments, although none appeared to perform satisfactorily in Curlew Valley. $M$. lupulina exhibited superior reseeding and ground cover characteristics compared to the other species.

$M$. lupulina (black medic or yellow trefoil) is widely distributed in North American as well as throughout the other temperate and subtropical regions of the world. Annual, biennial, and short-lived perennial forms exist (Turkington and Cavers 1979). Many varieties have been described because of the morphological diversity of the species (Lammerink 1968). Each population from a single site consisted of a number of genotypes in varying proportions which may shift when the population is moved to other habitats or climates. Wheeler (1950) indicated that black medic hay yields of 4.5 to 6.7 ton/ha were possible but that this species seldom was cut for hay. Wherever it thrives, black medic is a valued constituent of spring and early summer pastures. Blaser and Stokes (1946) described the characteristics of several black medic strains grown in
Florida. In the western United States, black medic was well nodulated and capable of fixing atmospheric nitrogen under range conditions (Baltensperger and Smith 1984; Johnson and Rumbaugh 1981; Smith and Baltensperger 1983, 1984). More detailed experiments showed fixation occurring even when soil water content reached as low as $8 \%$ (Holter 1978). Soil nitrogen accumulation in summer under medic swards can be independent of plant density or time of sowing and considerably higher than that in the absence of medics (Adem 1977). Koala and Sims (1982) reported that black medic increased wheat yields $92 \%$ and water use efficiency $81 \%$ in a ley farming experiment conducted near Bozeman, Mont.

Because $M$. lupulina is now distributed world-wide, natural selection probably would have differentiated the populations originating in different countries. Attributes of the $M$. lupulina populations tested are listed in Table 6. Introductions from Greece, Iran, Spain, U.S.S.R., and Yugoslavia excelled in reseeding ability. Individual accessions from some of the other countries also were able to reseed and also had high ground cover values. Most accessions were phenotypically heterogeneous and are expected to be genetically responsive to a variety of environmental circumstances (Lammerink 1968). An exceptionally broad and plastic germplasm base could be attained if several accessions or ecotypes were selected, the seed increased as separate populations, and the increase mechanically blended to form a seed mixture for pasture plantings or oversowing. Such a scheme would allow the release of one population with the capability of excelling in many kinds of sites (G.A. Gintzburger, unpublished).

\section{Conclusions}

Medicago lupulina (black medic) was better adapted to the environment of the northern Great Basin as exemplified by a Cache Valley, Utah, nursery site during the 3 years of experimentation than any of the annual species within that genus. While most medics grew well, were nodulated, and were capable of fixing atmospheric nitrogen, $M$. lupulina had superior reseeding and ground cover characteristics. Significant diversity was exhibited among the $70 \mathrm{M}$. lupulina introductions tested. Selected introduc-

Table 6. Characteristics of 70 Medicago lupulina accessions from 21 countries grown in Cache Valley, Utah.

\begin{tabular}{|c|c|c|c|c|c|c|c|c|c|}
\hline \multirow[b]{2}{*}{ Country } & \multirow{2}{*}{$\begin{array}{l}\text { Number of } \\
\text { accessions }\end{array}$} & \multicolumn{2}{|c|}{1981 day of first bloom } & \multicolumn{2}{|c|}{ Plant size $(\mathrm{cm})$} & \multicolumn{2}{|c|}{ Seedling density (number $/ \mathrm{m}$ ) } & \multicolumn{2}{|c|}{ Ground cover $(\%)$} \\
\hline & & Numerical & Date & Width & Height & $10-22-81$ & $07-10-82$ & $07-19-82$ & $05-25-83$ \\
\hline Afghanistan & 13 & 168 & 17 June & 154 & 22 & 1,118 & 3,765 & 89 & 55 \\
\hline Argentina & 1 & 156 & 5 June & 135 & 35 & 628 & 2,583 & 100 & 90 \\
\hline Australia & 1 & 162 & 11 June & 178 & 20 & 942 & 2,110 & 95 & 50 \\
\hline Austria & 1 & 169 & 18 June & 196 & 28 & 532 & 3,046 & 100 & 35 \\
\hline Czechoslovakia & 1 & 169 & 18 June & 129 & 29 & 1,304 & 3,003 & 100 & 70 \\
\hline Denmark & 3 & 176 & 25 June & 154 & 22 & 171 & 1,528 & 83 & 35 \\
\hline France & 3 & 171 & 20 June & 151 & 28 & 468 & 3,286 & 87 & 43 \\
\hline Great Britain & 3 & 162 & 11 June & 141 & 22 & 692 & 2,956 & 88 & 77 \\
\hline Greece & 1 & 187 & 6 July & 186 & 15 & 546 & 11,582 & 100 & 35 \\
\hline Hungary & 1 & 169 & 18 June & 150 & 37 & 434 & 3,810 & 100 & 75 \\
\hline Iran & 4 & 172 & 21 June & 174 & 20 & 918 & 5,051 & 98 & 41 \\
\hline Italy & 2 & 166 & 15 June & 173 & 22 & 672 & 3,794 & 100 & 42 \\
\hline Pakistan & 2 & 162 & II June & 102 & 16 & 2,213 & 2,093 & 88 & 68 \\
\hline Poland & 1 & 174 & 23 June & 187 & 26 & 10 & 1,787 & 95 & 50 \\
\hline Spain & 6 & 169 & 18 June & 160 & 19 & 1,158 & 6,946 & 97 & 46 \\
\hline Sweden & 1 & 194 & 13 July & 101 & 8 & 18 & 16 & 30 & 75 \\
\hline Switzerland & 2 & 169 & 18 June & 180 & 16 & 834 & 2,400 & 92 & 80 \\
\hline Turkey & 17 & 169 & 18 June & 154 & 20 & 755 & 3,206 & 88 & 50 \\
\hline Uruguay & 2 & 162 & 11 June & 134 & 33 & 1,517 & 2,756 & $\begin{array}{l}80 \\
88\end{array}$ & 45 \\
\hline U.S.S.R. & 2 & 172 & 21 June & 182 & 20 & 1,844 & 4,548 & 92 & 30 \\
\hline Yugoslavia & 3 & 169 & 18 June & 156 & 25 & 1,535 & 6,211 & 100 & 85 \\
\hline Mean & 3.3 & 169 & - & 155 & 22 & 931 & 3,806 & 91 & 54 \\
\hline L.S.D. (0.05) & - & 7 & - & 25 & 6 & 488 & N.S. & N.S. & 28 \\
\hline$(0.01)$ & - & 9 & - & 33 & 8 & 645 & N.S. & N.S. & N.S. \\
\hline
\end{tabular}


tions could be propagated separately and the seeds blended to form a single population potentially adapted to many kinds of pasture and range sites.

\section{Literature Cited}

Adem, L. 1977. Studies on the ecology and agronomy of annual Medicago species. M.S. Thesis. Univ. Adelaide.

Baltensperger, A.A., and M.A. Smith. 1984. Nitrogen fixation estimates for some native and introduced legumes, forbs, and shrubs. J. Range Manage. 37:77-78.

Blaser, R.E., and W.E. Stokes. 1946. Ecological and morphological characteristics of black medic strains. J. Amer. Soc. Agron. 38:325-331.

Clarkson, N.M., and J.S. Russell. 1976. Effect of water stress on the phasic development of annual Medicago species. Aust. J. Agr. Res. 27:227-234.

Davis, J.H., E.O. Gangstad, and H.L. Hackerott. 1957. Button clover. Hoblitzelle Agr. Lab., Texas Res. Found., Bull. 6.

Ewing, M.A. 1983. Medics return to favor. Western Australian Dep. Agr. J. Agr. 27-31.

Francis, C.M. 1981. The distribution and ecology of annual Medicago species in North West Libya. A report based on a plant collection tour. Aust. Plant Introd. Rev. 13:3-14.

Henson, P.R., and E.A. Hollowell. 1960. Winter annual legumes for the South. USDA Farmers' Bull. 2146.

Holter, V. 1978. Nitrogen fixation of four legumes in relation to aboveground biomass, root biomass, nodule number, and water content of the soil. Oikos 31:230-235.

Johnson, D.A., and M.D. Rumbaugh. 1981. Nodulation and acetylene reduction by certain legume species under field conditions. J. Range Manage. 34:178-181.
Koala, S., and J.R. Sims. 1982. Adaptation of Australian ley farming to Montana dryland cereal production. Agronomy Abst.

Lammerink, J. 1968. Genetic variability in commencement of flowering in Medicago lupulina L. in the South Island of New Zealand. N.Z.J. Bot. 6:33-42.

Lesins, K.A., and I. Lesins. 1979. Genus Medicago (Leguminosae)-A taxogenetic study. W. Junk, the Hauge.

Quinlivan, B.J. 1971. Seed coat impermeability in legumes. J. Aust. Inst. Agr. Sci. 37:283-295.

Scholander, P.F., H.T. Hammel, E.D. Bradstreet, and E.A. Hemmingsen. 1965. Sap pressure in vascular plants. Science 148:339-346.

Smith, M.A., and A.A. Baltensperger. 1983. Agronomic and acetylene reduction evaluation of three annual medics. J. Range Manage. 36:55-57.

Smith, M.A., and A.A. Baltensperger. 1984. Field performance of three annual medics. New Mexico Agr. Sta. Res. Rep. 525.

Tadmor, N.H., L. Shanan, and M. Evenari. 1971. "Runoff farming" in the desert. V. Persistence and yields of annual range species. Agron. J. 63:91-95.

Turkington, R., and P.B. Cavers. 1979. The biology of Canadian weeds, 33, Medicago lupulina L. Can. J. Plant Sci. 59:99-100.

Urban, I. 1873. Prodromus einer monographie der gattung Medicago $L$. Verh. bot. Ver. Brandenb. 15:1-85. Trans. by J.L. Bolton, H. Baenziger, and G.K.H.H. Thuns. Canada Agriculture.

Walter, H., and H. Lieth. 1960. Klimadiagramm-Weltatlas. G. Fisher Verlag, Jena.

Wheeler, W.A. 1950. Forage and pasture crops. D. Van Nostrand Co., New York. 